\title{
STRENGTHENING THE SUPERVISION OF MARKET CONDUCT OF BANKING FINANCIAL SERVICES BY FINANCIAL SERVICE AUTHORITY (OJK) IN CENTRAL JAVA ${ }^{\Omega}$
}

\author{
Sulistyandari, Noor Aziz Said and MI Wiwik Yuni Hastuti \\ Faculty of Law, Universitas Jenderal Soedirman \\ E-mail: sulistyandari265@yahoo.co.id
}

\begin{abstract}
This study aims to assess and find weaknesses regulation and supervision of market conduct banking financial services, and find weaknesses supervision of market conduct banking financial services in the region of Central Java and offer for solutions. The results show that Financial Service Authority/ FSA (known as OJK) Law and POJK Number 01/POJK.07/ 2013 are the governing authority of the OJK under the supervision of market conduct financial services. Until present, BI Law and Banking Law have not set about it. In the future market surveillance authorities conduct financial services under the authority of $\mathrm{BI}$ and the OJK, these two institutions share in accordance with the authority given to legislation. Supervision of market conduct banking financial services by the OJK overall is only implemented by the Office of Central OJK. While the OJK in Central Java has new obligations education and service consumer complaints so the protection of consumers of financial services has not been optimally implemented at the Central Java OJK office.
\end{abstract}

Keywords : financial market conduct, OJK, supervision

\begin{abstract}
ABSTRAK
Penelitian ini bertujuan mengkaji dan menemukan kelemahan pengaturan dan pengawasan market conduct jasa keuangan perbankan, menemukan kelemahan pelaksanaan pengawasan market conduct jasa keuangan perbankan di wilayah Jawa Tengah dan memberikan solusi penguatannya. Hasil penelitian menunjukkan bahwa Undang-Undang Otoritas Jasa Keuangan (OJK) dan Peraturan Otoritas Jasa Keuangan (POJK) No. 01/POJK.07/2013 mengatur kewenangan OJK dalam pengawasan market conduct jasa keuangan. Sampai saat ini UU BI dan UU Perbankan belum mengatur tentang hal tersebut. Kedepan kewenangan pengawasan market conduct jasa keuangan menjadi kewenangan $\mathrm{BI}$ dan OJK, dua lembaga ini berbagi sesuai dengan kewenangan yang diberikan perUUan. Pelaksanaan pengawasan market conduct jasa keuangan perbankan oleh OJK, secara keseluruhan baru dilaksanakan oleh Kantor OJK Pusat. Sementara OJK di wilayah Jawa Tengah baru melaksanakan kewajiban edukasi dan pelayanan pengaduan konsumen, sehingga perlindungan konsumen jasa keuangan belum dilaksanakan secara maksimal di kantor OJK wilayah Jawa Tengah.
\end{abstract}

Kata kunci: Market conduct keuangan, OJK, pengawasan

\section{Introduction}

One objective of the establishment of the Financial Services Authority (OJK) is to be able to protect the consumer's interests in the financial services sector. Consequently, OJK Regulation Number 01/POJK.07/2013 on July $26^{\text {th }} 2013$ concerning Consumer Protection in the Financial Services Sector has been issued. The goal is to

$\Omega$ Unsoed Leading Research Results with a Decree of the Head of LPPM Unsoed Number: 4030/UN23.14/PN.01.00/ 2016 create a reliable system of consumer protection, increasing consumer empowerment, and raising awareness of the Financial Services Business Actor (PUJK) about the importance of consumer protection to increase public confidence in financial services sector. This POJK is a law patronage for regulating the consumer protection in financial services sector in Indonesia. Regarding to this, OJK shall conduct supervision of market conduct in the field of financial services as a financial services consumer protection. 
OJK authority in regulation and supervision of financial services includes banking and nonbanking financial services. ${ }^{1}$ Since December $31^{\text {st }}$ 2013, OJK legally has the authority regulation and supervision of banking which was originally under the authority of Bank Indonesia (BI). ${ }^{2}$ The authority in question is authority of prudential regulation and supervision (micro prudential). ${ }^{3}$ By the Law enactment Number 21 Year 2011 concerning OJK (OJK Law), OJK not only has prudential supervisory authority but also market conduct financial services supervisory authority. Thus in Indonesia prudential supervisory authority and market conduct financial services are in the hands of an institution that is OJK, an independent institution of financial services authority. ${ }^{4}$

Based on the survey of 35 OECD (Organization for Economic Corporation Development) members including USA and UK, the post 2008 crisis of these countries pay attention to market conduct supervision of financial services. In this context, the main function of market conduct supervisory authority is to monitor compliance with financial actor to legal obligations and take steps in infringement event cases as the result of consumer complaints. ${ }^{5}$ In the UK market conduct supervision is carried out by a specialized institution. ${ }^{6}$

The implementation of assessment market conduct of financial services in Indonesia was carried out in 2015, and until January $16^{\text {th }} 2015$ in the Office of Central OJK already exists 3,118 complaints which most come from the banking sector related to collateral, credit restructuring, and Card Payment Instruments (APMK) such as credit cards, debit and e-money. According to

1 Nova Asmirawati, "Catatan Singkat Terhadap Undang-Undang Nomor 21 Tahun 2012 Tentang Otoritas Jasa Keuangan”, Majalah Legalitas, Vol. 9 No. 3, 2012, Jakarta: Ministry of Law and Human Rights, page 449-558.

2 Ahmad Solahudin, "Pemisahan Kewenangan Bank Indonesia dengan Otoritas Jasa Keuangan Dalam Pengawasan", Jurnal IUS Kajian Hukum Dan Keadilan, Vol. III No.7 April 2015, Jakarta: Universitas Mataram, page 108-128.

3 Lina Maulidiana, "Fungsi Otoritas Jasa Keuangan Sebagai Lembaga Pengawas Perbankan Nasional Di Indonesia", Jurnal Keadilan Progresif, Vol. 5 No. 1, Maret 2014, Lampung: Law Studies Program Universitas Bandar Lampung, page 103-120.

4 Bismar Nasution, "Struktur Regulasi Independen Otoritas Jasa Keuangan”, Jurnal Hukum Dan Peradilan, Vol. 03 the OJK Board of Commissioners Kusumaningtuti $S$ Setiono, the implementation of assessment market conduct will hit the violations in the financial services industry, especially banking. Related to the foregoing by the House Commission XI Member, Andreas Susetyo Eddy, the OJK should strengthen the supervision of market conduct. Strengthening supervision is not only on aspects of rules but also the ability of inspectors in all OJK offices from central to local level. The strengthening is intended to prevent potential losses on consumer financial services, and even supervisors can take action if it proves violations. Thus there are still weaknesses on the regulation and the implementation of market conduct supervision of financial services considering market conduct supervision of financial services relatively new in Indonesia.

This study will discuss the strengthening of market conduct supervision of banking financial services as an effort of consumer protection in the region of Central Java. This study is important because it will inform the issues about weaknesses in regulation and implementation of market conduct supervision of financial services that could potentially cause harm to consumers and a lack of public confidence in the financial services institutions. Therefore strengthening the supervision of financial services business behavior is necessary as a consumer protection either normative or implementative in Central Java.

\section{Problems}

Based on the background, the problem statements are then formulated as follows. First, how the market conduct regulation and supervision of banking financial services as consumer

No. 3, November 2014, Jakarta: Mahkamah Agung RI, page 281-292; Wiwin Sri Rahyani, “Independensi Otoritas Jasa Keuangan dalam Perspektif Undang-Undang Nomor 21 Tahun 2011 tentang Otoritas Jasa Keuangan", Majalah Legalitas, Vol. 9 No. 3. 2012, Jakarta: Kementerian Hukum dan Hak Asasi Manusia, page 361-372.

5 Directorate For Financial and Enterprise Affairs, “Addressing Financial Consumer Protection Deficiencies In The Post Crisis Era," OECD Journal, 31 March 2010, London: Brunel University, page 1-23.

6 Yong-Woo Lee, "International Finance The Breakup of The UK Financial Service Authority and The Implication", Capital Market Perspective e-Journal, Vol. 4 No. 2, 2012, Seoul: Korea Market Capital Institute, page 62-77. 
protection; and second, how the implementation of market conduct supervision of banking financial services by the OJK as consumer protection efforts in Central Java.

\section{Research methods}

This is a qualitative study with normative juridical approach and the study of law as the law in action, a social science studies that nondoctrinal and empirical. Research location is in Central Java OJK Office. The research data were derived from primary data taken from the OJK Central Java region (Purwokerto, Tegal, Solo and Semarang) and Banking Financial Services Business Actor (PUJK). The secondary data were in the form of legislation, a draft (RUU), textbooks, scientific journals, and documents which relates to the object of this study. The data collection method uses content analysis, interviews and observation. The data analysis was done by interpreting data based on norms and law theories especially the law of financial services institutions, civil law, administrative law and theory of law enforcement.

\section{Discussion}

Regulation and supervision of market conduct of finance banking as consumer protection efforts

The broad terms of market conduct supervision and consumer protection are the elements of financial regulation and supervision focusing on the behavior of financial institutions, including non-distortive and non-abusive business practices, and disclosure of information in providing services to retail consumers. In other words, it involves market conduct supervision, including supervision of financial consumer protection. In Armenia, the prudential supervisory authority and market conduct of financial services is in the Central Bank of Armenia (CBA) based on Central Bank Law. ${ }^{7}$

In Indonesia, the definition of market conduct is the behavior of financial services business actors in designing, preparing and delivering in-

Johanna Jaeger and Angela Prigozhina, "Financial Inclusion and Infrastructure Global Practice Market Conduct Supervision in Small Countries: The Case of Armenia", formation, offering, making an agreement, for the products and/or services as well as dispute resolution and complaints handling. The aim is to create a reliable system of consumer protection, increasing consumer empowerment, and raising awareness of Financial Services Business Actor (PUJK) about the importance of consumer protection so as to increase public confidence in financial services sector

Market conduct regulation and supervision of financial services (including banking) are governed by POJK Number 1/POJK.7/2013 concerning Consumer Protection. This POJK is an implementation of OJK Law. POJK has been followed up by Financial Services Authority Commissioner Council Regulation Number 2 /PDK.07/2015 concerning Monitoring and Analyzing of Consumer Protection in the Financial Services Sector.

Articles 5 and 6 of OJK Law determine that the OJK functions to implement the integrated regulation and supervision of the overall activities in the financial services sector, and OJK carry out the task of supervising and regulating financial services. OJK authority in the regulation and supervision of Financial Service Business Authority/ FSBA (PUJK) banking stipulated in Article 7 of OJK Law. Regulation and supervision in question is micro prudential regulation and supervision. In addition, Article 4 of OJK Law determines that one purpose of the OJK establishments is to protect the interests of consumers and society as a whole in the financial services sector. Consequently, within the structure of OJK Commissioners Board one of which consists of one member who has a role in education and consumer protection to realize the objectives of the OJK establishment, and by the issuance of POJK Number 01/POJK 07/2013 concerning Consumers Financial Services Protection, the OJK has the authority to supervise compliance with obligations of POJK Number 01/POJK 07/2013 by PUJK, OJK supervision is called market conduct supervision. Thus the OJK has authority of regulation and supervision of micro-prudential and market conduct.

Financial \& Private Sector Development Journal, March 2013, Swiss: Federal Departement of Economic Affairs, Education and Research EAER, page 1-6. 
Law Number 23 Year 1999 concerning Bank Indonesia as amended by Law NNumber 3 Year 2004 and Law Number 6 Year 2009 (BI Law) and Law Number 7 Year 1992 concerning Banking as amended by Law Number 10 Year 1998 (Banking Law) until present are not amendment yet. Hence, if we only read the BI Law and the Banking Law, we will not see the authority of the OJK in carrying out the regulation and supervision of the PUJK. The authority of the OJK to conduct regulation and supervision of micro-prudential and market conduct is governed in the OJK Law. Therefore, the BI law draft and Banking law draft have been prepared as an amendment to the $\mathrm{BI}$ Law and Banking Law.

Article 16 of the $\mathrm{BI}$ law draft, governing the $\mathrm{BI}$ authority to regulate and licenses, develops and supervises the business activities of nonbank foreign exchange. Then Article 32 governs $\mathrm{BI}$ the authority to regulate and supervise the application of the principle of protection of consumers from service providers of payment systems and the management of rupiah. Consumer protection includes education, consulting and facilitation. Further provisions shall be governed by Bank Indonesia Regulation (PBI).

Article 10 of the Banking law draft stipulates that licenses of the business banks is given to $\mathrm{OJK}$ and $\mathrm{BI}$ in accordance with their respective authorities as stipulated in Law. Article 98 stipulates that the Bank is obliged to provide protection to every customer in the banking activities. Regulation and supervision to the provision of customer protection in order to market conduct supervision is established by OJK.

If we look at the BI law draft and the banking law draft also OJK Law, it can be seen that both $\mathrm{BI}$ and OJK has the authority to grant permission business activities in accordance with their authority. BI has the authority to grant permission effort to PUJK service providers of payment systems and PUJK conducting business foreign exchange is not a bank, thus, BI has the authority to regulate and supervise the application of the principles of consumer protection covering education, consulting and facilitation regulated in Bank Indonesia Regulation (PBI) Number 16/ 1/pbi/2014 concerning Consumer Protection Service Payment System. Meanwhile, OJK has the authority to permit business activities to banking and non-banking PUJK in addition to the authority $\mathrm{BI}$ above, and OJK has the authority to regulate and supervise the application of the consumer protection covering education principles, consulting and facilitation, as provided in Financial Service Authority Regulation (POJK) is POJK Number 01/POJK.07/2013 concerning Consumer Protection financial Services. Thus the authors can conclude that in the future the authority and supervision of market conduct regulation or PUJK business conduct, actually become the authority of OJK and BI. Further, the division is in accordance with the authority granted by the BI law draft, Banking law draft and OJK Law. Similarly, the authority to regulate and supervise the application of the principles of consumer protection involve education, consulting and facilitation.

Thus today there are still weaknesses in the regulation of the supervisory authority of market conduct. As a result, the immediate reinforcement of the BI Law, Banking Law and the Law on the OJK amended necessarily needed so that there is legal certainty to the authority of the $\mathrm{BI}$ and the OJK in the regulation and supervision of market conduct PUJK banking.

Implementation of market conduct supervision of the banking financial services by the OJK as consumer protection efforts in Central Java.

According to the study of administrative law, supervision is part of the aspects of legal enforcement that the instruments include: supervision and sanctions. Supervision is performed through obedient citizens to provisions that are mandatory or prohibited provisions are not violated. Sanction is also an instrument imposition. ${ }^{8}$

The main problems of law enforcement lies in factors that may affect it. These factors are factors of law itself, law enforcement fac-

Tatiek Sri Djatmiati, 2004, Prinsip Izin Usaha Industri Di Indonesia, Surabaya: Postgraduate Program Universitas Airlangga, page 81-82. 
tors, namely the parties that form and applying the law, Factor facility, which supports the rule of law, society factors, the environment in which they may apply or applied. Cultural factors, namely as a work of authorship, and the sense is based on human initiative in social life. These five factors are closely interrelated and constitute the essence of the rule of law as well as a measure of the effectiveness of law enforcement. These factors have the neutral meaning, thus, a positive or negative impact lies in the content of these factors. ${ }^{9}$

Based on the results of the OJK research in Central Java, there were four OJK offices namely Purwokerto, Tegal, Solo, Semarang, and the number of PJUK banking under the supervision of the OJK respectively as follows: Purwokerto 26 BPR/S headquarters; Tegal 32 BPR/S Headquarters; Solo 82 BPR/S headquarters, and Semarang $138 \mathrm{BPR} / \mathrm{S}$ headquarters and 1 commercial bank.

The research showed the number of consumer complaints against PJUK banking on each OJK as follows: Purwokerto 50 complaints (till July 2016); Tegal 20 complaints (till June 2016); Solo 27 complaints (till July 2016); Semarang 170 complaints (till August 2016).

Based on the results of complaint research issues by the Consumer banking in OJK of Central Java region include: Nonperforming loans like debt restructuring, request waivers of loan installment, auction of collateral, the collateral document is missing; Error recording of debtor information system reports (SID); ATM fraud (skimming and phishing); The blocking of the account; Transparency of costs; and credit cards.

The research data show that the supervision of market conduct by POJK Number 1/POJK. 07 /2013 as a whole just been implemented by the Central Office of OJK in Market Conduct Directorate. While the OJK in the region of Central Java (Purwokerto, Tegal, Solo, Semarang) just implemented obligations that must be implemented in POJK Number 1/POJK.07/2013, ie PUJK obliged to carry out educational functions and serve consumer complaints. Periodically,
PUJK banking in Central Java has submitted a report and implementation plan of education, as well as consumer complaint report. Furthermore, to assess whether PUJK has implemented POJK Number 1/POJK.07/2013, the OJK requires that PUJK to submit Annual Self-Assessment reports in June up to September 30.

Based on the research, data show that in accordance with Article 35 paragraph (1) POJK Number 1/POJK.07/2013, PUJK shall promptly follow up and resolve the complaint no later than 20 working days after the date of receipt of the complaint. So far, there are PUJK that have not been able to meet the obligations of consumer complaints resolution at most 20 working days although few PUJK have not met such obligations. However, OJK appealing to PUJK immediately follows consumer complaint in accordance with the provisions of a maximum of 20 working days. If in certain cases PUJK require additional time, in accordance with Article 35 paragraph (2), PUJK may extend the period up to a following maximum of 20 working days and shall be submitted in writing to the Consumer.

Based on the results of the research, the data show that the constraints of PUJK banking that have not obligations of POJK Number 1/ POJK.07/2013 in OJK Central Java office include the following. First, given PUJK in Central Java is largely a branch office so some require longer time to coordinate with the central office. As a result, fulfilling the obligations of complaints resolution a maximum of 20 working days could not be met. In addition, the lack of understanding by PUJK to inform the complaints resolution process conducted by PUJK to consumers; and second, some PUJK small-scale banking do not have a consumer complaint units and human resources to handle consumer complaints unified with the CS (customer service).

Furthermore, the data showed that the OJK in an effort to encourage PUJK banking in compliance with their obligation of POJK provisions Number 1/ POJK.07/2013 is to socialize and refreshment POJK provisions Number 1/POJK. 
07/2013 to FSBA(PUJK) residing in the KR 3 Central Java and Yogyakarta at least once a year. Based on OJK opinion on regulatory oversight of market conduct (business conduct), it is identified that first, POJK Number 01/POJK.07/2013 has been clearly implemented through Regulation of the Financial Services Authority Board of Commissioners Number 2/PDK.07/2015 concerning Monitoring and Analysis of Consumer Protection in the Financial Services Sector; second, the regulation has covered the entire scope of market conduct supervision including guidelines for the implementation, monitoring and analysis of consumer protection; and third, in general, the OJK has not socialized regulation to the PUJK Banking because the Regulations on Market Conduct is the internal regulations of the OJK conveyed through Council Commissioner Regulation. Consequently, PUJK has not been given an understanding directly on Market Conduct. However, a brief explanation of the Market Conduct delivered on POJK explanation Number 1/POJK.07/ 2013 is given. Market conduct implementation is applied equally between foster the financial services sector with the fulfillment of rights and obligations of consumers to increase consumer confidence.

Moreover, self-evaluation of the Market conduct supervision implementation at the OJK office in Central Java go for several reason: first, because market conduct is still under the authority of the OJK Centre, Central Java OJK implement supervisory authority of the PUJK to educational function and consumer complaints report. Thus, the OJK only has the consumer complaints unit. Supervision Implementation is not carried out simultaneously with prudential examination but sometimes in practice it requires information from the prudential supervision; second, specific inspectors to supervise the market conduct is not available while the prudential supervisor is very limited, the ideal ratio of the number of inspectors toward the number of supervised banks is $1: 4$, but the OJK Solo ratio was 1: 9. This is due to several supervisors opt back into $\mathrm{BI}$ employees so the OJK self-evaluation especially Solo requires the addition of supervisors and received training in the market conduct supervision; and Third, infrastructure related to market conduct supervision is immediately prepared.

The data of PUJK Banking reveals that PUJK gained supervision of the OJK; Supervision by the OJK conducted annually by the examination and evaluation report of the Bank; OJK examination to PUJK related to the prudential supervision and consumer protection; 2-3 OJK supervisors performed the examination; Some PUJK claimed receiving consumer complaints related to credit arrears; Some PUJK claimed they do not to have working units that handle and resolve consumer's complaints.

To sum up, supervision of market conduct banking financial services by the OJK as a whole has just been implemented by the OJK Central Office in Market Conduct Directorat. Menwhile, the Central Java OJK (Purwokerto, Tegal, Solo, Semarang) recently implement the obligations in accoordance with POJK Number 1/POJK.07/ 2013, ie PUJK is obliged to carry out the function of education and consumer complaint services. Thus the financial services consumer protection has not been maximized considering some obligations aimed to protect the consumer has not been implemented by Central Java PUJK banking.

Factors affecting the implementation of the market conduct supervision of FSBA(PUJK) banking by the OJK in Central are explained as follows; first, legal factors, POJK Number 1/ POJK.07/2013 as the regulations governing the business conduct supervision (market conduct) PUJK banking by OJK is clear enough by implementing regulations, namely Regulations of Financial Services Authority Board of Commissioners Number 2/PDK.07/2015 concerning Monitoring and Analysis of Consumer Protection in the Financial Services Sector. Yet, the Central Java OJK has not been fully applied, the socialization of these provisions is not generally implemented by the OJK offices in Central Java, except Semarang OJK Office Regional 3; second, Law enforcement factors namely the POJK obligation Number $1 /$ POJK.07/2013 as the regulations governing the business conduct supervision (market conduct) PUJK banking implemented in OJK offices in Cen- 
tral Java is the obligation of education and customer complaints services. There are several $\mathrm{BPR} / \mathrm{S}$ that do not receive consumer complaints units and its HR was unified with Customer Service (CS), as well as the time of handling consumer complaints has not been maximized as determined. Nevertheless, the OJK as supervisors (law enforcement) do not perform their duty. Rather, they provide additional time to PUJK to resolve the consumer complaint; third, facility factors that support law enforcement include HR Supervisors of OJK itself. Central Java OJK Supervisors to supervise micro prudential still are less than PUJK supervised especially when it combined with supervising the business conduct (market conduct). Therefore, OJK offices in Central Java region need to be prepared a special division dealing with market conduct supervision; fourth, community factors, in terms of people who are subject to the law, there are several $\mathrm{BPR} / \mathrm{S}$ which do not have any consumer complaints unit and its HR was unified with Customer Service (CS). Besides, there is a lack of time allotment in handling consumer complaint; and fifth, cultural factors, public awareness of consumers on their rights is well since the OJK educated the consumer on a regular basis. In addition to educating the consumer it is the responsibility of PUJK in an effort to provide consumer protection in accordance with POJK Number 1/ POJK.07/2013.

Therefore, it is necessary to strengthen the implementation of regulation and supervision of market conduct by the OJK in Central Java Region namely the implementation of all the provisions POJK Number 1/POJK.7/2013 which create market conduct supervision unit in the Central Java OJK, add HR supervisors, enforcing sanction, and enhancing education of PUJK to get more consumers.

\section{Conclusion}

BI Law and Banking Law so far have not set up the authority of the OJK role in market conduct regulation and supervision of the PUJK banking. The OJK authority contained in OJK Law as stipulated in POJK Number 01/POJK.07/2013 and Regulation of the Board of Commissioners of the Financial Services Authority Number 2/POJK. 07/2015. Nevertheless, in the future (BI law draft and Banking law draft), authorities of PUJK mar-ket conduct supervision authority becomes $\mathrm{BI}$ and the OJK, that is, BI has the authority to regu-late and supervise the market conduct PUJK ser-vice providers of payment systems and it is not bank conducting PUJK foreign currency exchange business. Besides, OJK has the authority to regu-late and supervise the market conduct of banks and non-bank of PUJK besides the authority of $\mathrm{BI}$ above.

Supervision of market conduct banking financial services by OJK has just been fully implemented by the Central Office of the OJK in Market Conduct Directorate. Meanwhile, the OJK in the region of Central Java implemented the obligations of consumer education and service complaints as stipulated in POJK Number 1/ POJK. $07 / 2013$ recently. Thus the protection of consumers of financial services have not been optimally implemented at the OJK office of Central Java. Factors law, law enforcement, facilities, people and cultural influencs market conduct supervision at the OJK office of Central Java.

\section{Suggestion}

Based on the analysis, suggestions are proposed as follows. First, POJK Number 1/ POJK.07/2013 concerning Financial Services Consumer Protection and Regulation of Financial Services Authority Board of Commissioners Number 2/PDK.07/2015 about Monitoring and Analysis of Consumer Protection in the Financial Services Sector shall be socialized to PUJK as a preparation for the implementation of these provisions in the OJK office of Central Java. BI Law and the Banking Law need to be amended immediately to the legal certainty the authority of the OJK to strengthen the regulation and supervision of market conduct; Second, it should immediately form unit/ division of supervising market conduct in OJK office of Central Java and provide adequate supervisors, the human resources skill and competence to support supervising market conduct financial services from central to local leve. By so doing, it can prevent potential loss to consumers of financial services. 


\section{References}

Asmirawati, Nova. "Catatan Singkat Terhadap Undang-Undang Nomor 21 Tahun 2012 Tentang Otoritas Jasa Keuangan”. Majalah Legalitas. Vol. 9 No. 3. 2012. Jakarta: Ministry of Law and Human Rights of Republic of Indonesia;

Directorate For Financial and Eterprise Affairs, "Addressing Financial Consumer Protection Deficiencies In The Post Crisis Era", OECD Journal, March $31^{\text {st }}$ 2010, London: Brunel University;

Djatmiati, Tatiek Sri. 2004. Prinsip Izin Usaha Industri Di Indonesia. Surabaya: Postgraduate Program Universitas Airlangga;

Jaeger, Johanna and Angela Prigozhina. "Financial Inclusion \& Infrastructure Global Practice Market conduct Supervision in Small Countries: The Case of Armenia". Financial and Private Sector Development Journal. March 2013. Swiss: Federal Departement of Economic Affairs. Education and Research EAER;

Lee, Yong-Woo. "International Finance The Break up of The UK Financial Service Authority and The Implication". Capital Market Perspecive e-Journal. Vol. 4 No 2. 2012. Seoul: Korea Market Capital Institute;

Maulidiana, Lina. “Fungsi Otoritas Jasa Keuangan Sebagai Lembaga Pengawas Perbankan Nasional Di Indonesia”. Jurnal Keadilan Progresif. Vol. 5 No. 1. March 2014. Lampung: Law Studies Study Program Universitas Bandar Lampung;

Nasution, Bismar. "Struktur Regulasi Independen Otoritas Jasa Keuangan". Jurnal Hukum dan Peradilan, Vol. 03 No. 3. November 2014. Jakarta: Mahkamah Konstitusi of Republic of Indonesia;

Rahyani, Wiwin Sri. “Independensi Otoritas Jasa Keuangan dalam Perspektif Undang-Undang Nomor 21 Tahun 2011 tentang Otoritas Jasa Keuangan". Majalah Legalitas. Vol. 9 No. 3. 2012. Jakarta: Ministry of Law and Human Rights of Republic of Indonesia;
Soekanto, Soerjono. 2011. Faktor-Faktor Yang Mempengaruhi Penegakan Hukum. Jakarta: Raja Grafindo Persada;

Solahudin, Ahmad. "Pemisahan Kewenangan Bank Indonesia Dengan Otoritas Jasa Keuangan Dalam Pengawasan". Jurnal IUS Kajian Hukum Dan Keadilan. Vol. III No. 7. April 2015. Jakarta: Universitas Mataram. 